\title{
INVESTIGATION AND REMEDIATION OF THE CAVERN IN THE VRATA TUNNEL ON THE ZAGREB - RIJEKA HIGHWAY (CROATIA)
}

\author{
RAZISKAVE IN REMEDIACIJA JAMSKE DVORANE V PREDORU \\ VRATA NA AVTOCESTI ZAGREB - REKA (HRVAŠKA)
}

\author{
Mladen GARAŠIĆ ${ }^{1,2}$, Meho Saša KOVAČEVIĆ ${ }^{1} \&$ Danijela JURIĆ-KAĆUNIĆ
}

\begin{abstract}
UDC 911.2:551.44(234.422.1)

Mladen Garašić, Meho Saša Kovačević \& Danijela JurićKaćunić: Investigation and remediation of the cavern in the Vrata tunnel on the Zagreb - Rijeka highway (Croatia)

In the Dinaric karst system in Croatia some 11500 speleological objects have been explored so far, more than 1000 of which were discovered during construction works. Such speleological objects without natural entrance on the terrain surface (which are called "caverns") have been discovered on the construction sites of the highways. Over the past twenty years they have been systematically investigated and treated. A special kind of remediation was conducted in the cavern's large hall of the „Vrata" tunnel on the Zagreb - Rijeka highway. Due to size, shape, cavern's position and hydrogeological parameters within the karst system it was necessary to design and construct a 58 $\mathrm{m}$ bridge over the cavern. In addition, the cavern's vault had to be reinforced and stabilized, as the overburden was very thin. The beam-and -stringer grid with special anchors was used.

The cavern's rehabilitation in the "Vrata" tunnel was a unique undertaking, and the bridge (without piers) is the cavern's longest bridge in the world.
\end{abstract}

Keywords: speleology, cave, Dinaric karst, Croatia, tunnel, karst phenomena, geotechnical engineering.
Izvleček

UDK 911.2:551.44(234.422.1)

Mladen Garašić, Meho Saša Kovačević \& Danijela JurićKaćunić: Raziskave in remediacija jamske dvorane $v$ predoru Vrata na avtocesti Zagreb - Reka (Hrvaška)

V hrvaškem delu Dinarskega krasa je raziskanih preko 11500 jam, od teh je bilo več kot tisoč odkritih med gradbenimi deli. Večino teh, ki sicer nimajo naravnega vhoda s površja, so odkrili med gradnjo avtocest. Te jame sistematični raziskujemo zadnjih dvajset let. V članku predstavimo več izvirnih tehničnih rešitev, ki so jih izvedli za ohranitev velike podzemne dvorane, odkrite med gradnjo predora Vrata na avtocesti Zagreb Reka. Dvorana, ki jo seka predor, je zaradi velikosti in hidrogeološkega pomena predstavljala velik geotehnični izziv. Preko dvorane so speljali $58 \mathrm{~m}$ dolg most, poleg tega pa so morali ojačiti in stabilizirati svod, ker je debelina skladov nad dvorano majhna. $\mathrm{V}$ ta namen so izdelali mrežo nosilcev in gredi, ki so jo učvrstili s posebnimi pritrdišči. Most, ki je brez podpornih stebrov, je najdaljši most $\mathrm{v}$ jami na svetu.

Ključne besede: speleologija, jama, Dinarski kras, Hrvaška, predor, kraški fenomeni, geotehnični inženiring.

\section{INTRODUCTION}

The Zagreb-Rijeka highway connects the inland (lowland), and hilly and Adriatic (karst) parts of Croatia (Fig. 1). Its construction started in 1971, and reached the karst area in 1991. It was open for traffic in 2004, but it was completed in its full profile only late in 2008.
The highway construction in the karst area presents quite a difficult task due to numerous karstic voids, which were not previously discovered during the investigations (geophysical methods, investigation borings).

\footnotetext{
${ }^{1}$ University of Zagreb, Faculty of Civil Engineering, Geotechical Department, HR-10000 Zagreb, Kačićeva 26, Croatia, e-mail: mgarasic@grad.hr; msk@grad.hr,dkacunic@grad.hr

${ }^{2}$ Croatian Speleological Federation, HR-10000 Zagreb, Nova Ves 66, Croatia, e-mail: speleo@speleo.hr

Received/Prejeto: 29.10.2009
} 


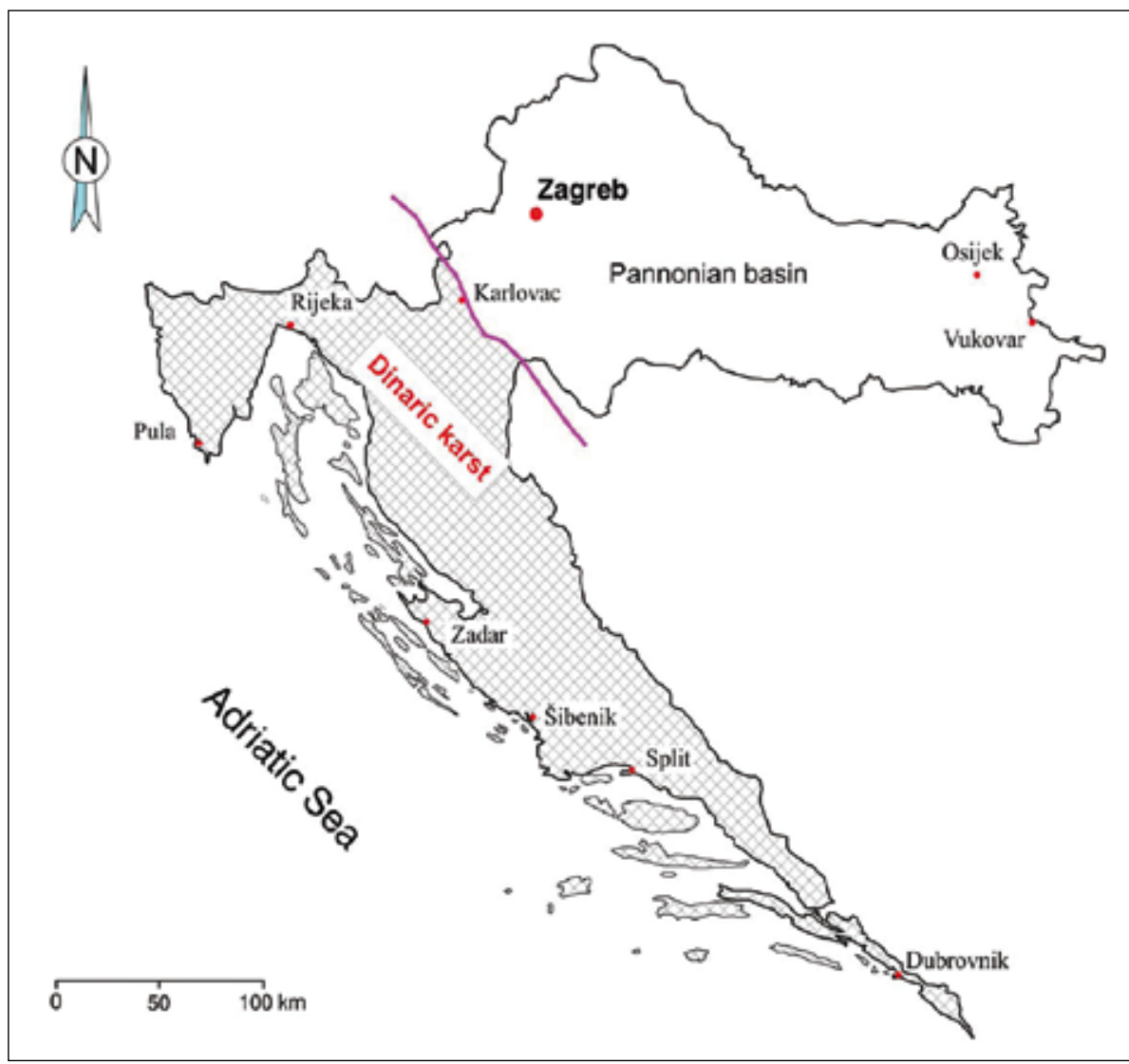

Fig. 1: Croatian karst area and location of Zagreb and Rijeka towns.

For more than 18 years the speleologists have been continuously exploring all discovered caverns. Along the Zagreb-Rijeka highway a total of 327 caverns were discovered (Garašić 1981; Garašić \& Bočić 2006; Garašić 2007).

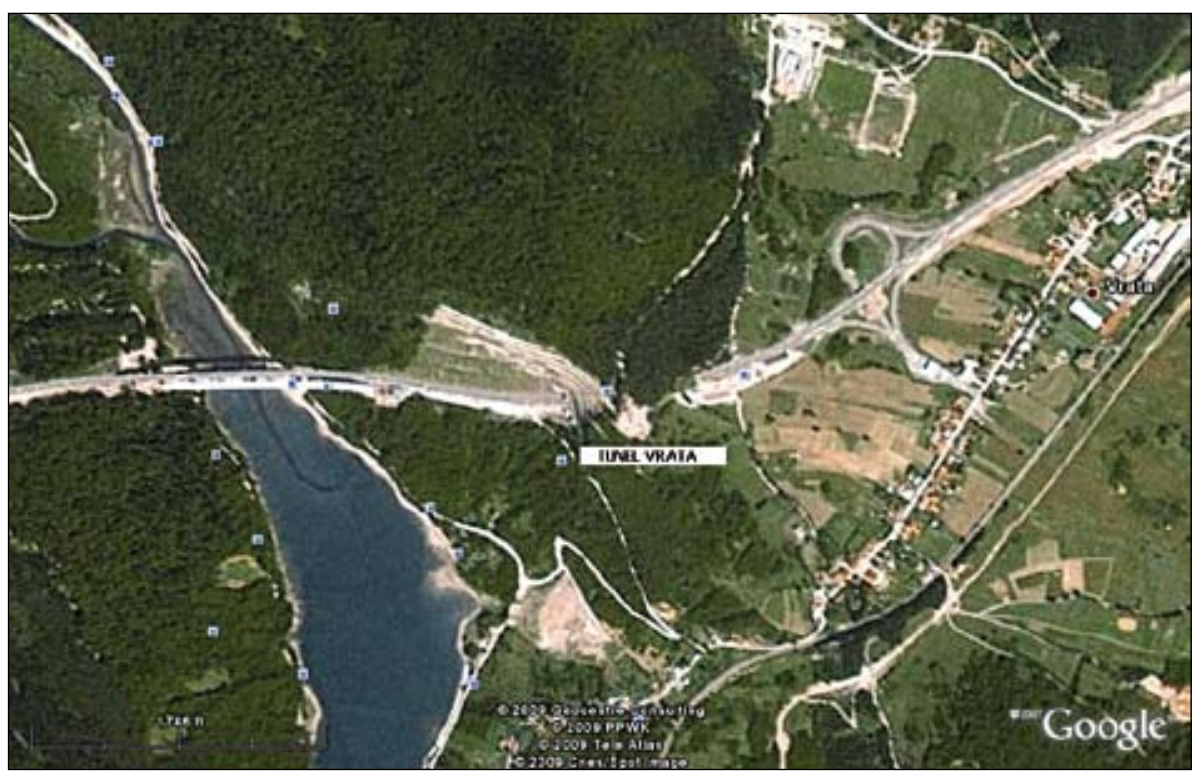

Fig. 2: The location of tunnel "Vrata" on highway Zagreb - Rijeka.
The first left $257 \mathrm{~m}$ long "Vrata" tunnel tube (LTT) was constructed as a two lane tunnel with two traffic lanes, one in the $\mathrm{Ri}$ jeka direction and the other one in the Zagreb direction. It was open for traffic in the first phase of the highway construction in 1994 (Fig. 2). The cross section of the left tube satisfies the free profile dimensions in the tunnel in relationship to traffic elements of route mapping and roadway warping. Until the right tunnel tube was open for traffic (2008) it was a two way tunnel.

During the excavation of the second tube, which is one of the shortest tunnels on the mentioned highway, a large cavern was discovered in the „Vrata“ tunnel late in 2006. The right "Vrata" tunnel tube was (RTT) $262 \mathrm{~m}$ long, from $\mathrm{km} 31+168$ to $\mathrm{km} 31+430$.

During the right tube excavation the works were conducted on both tunnel portals (on the eastern and on the western one), from the western portal beginning to $\mathrm{km} 31+260$, and from the eastern portal to $\mathrm{km} 31+291$.

During the eastern side excavation on $\mathrm{km} 31+293$ the underground hall (cavern) was discovered stretching along the whole tunnel's profile, but also outside the profile up to $\mathrm{km} 31+260$. The tunnel orientation is approximately west-east $\left(260^{\circ}-80^{\circ}\right)$.

The tunnel excavation and excavation stabilization were designed according to the NATM (New Austrian Tunnel Method). It implied, as its primary objective in stabilization of underground excavation, the applying of the bearing capacity of the rock mass itself in which the tunnel excavation was car- 
ried out, as the main bearing element in the interactive system of support and rock mass.

Excavation works started in July 2006 on the eastern side. The tunnel excavation involved careful blasting and partially mechanical activities (excavation hammer), and the combination of both ways. The tunnel tube excavation was initiated on $27^{\text {th }}$ October 2006, and the tunnel's average progress was some $2.5 \mathrm{~m} /$ day.

The large cavern's thin overburden located in the layer with ground water between the Vratarka swallow hole and the Potkoš source imposed the need for speleological, speleohydrogeological, geological and geotechnical works. This paper addresses only the most important results aiming to provide the safest stabilization of the

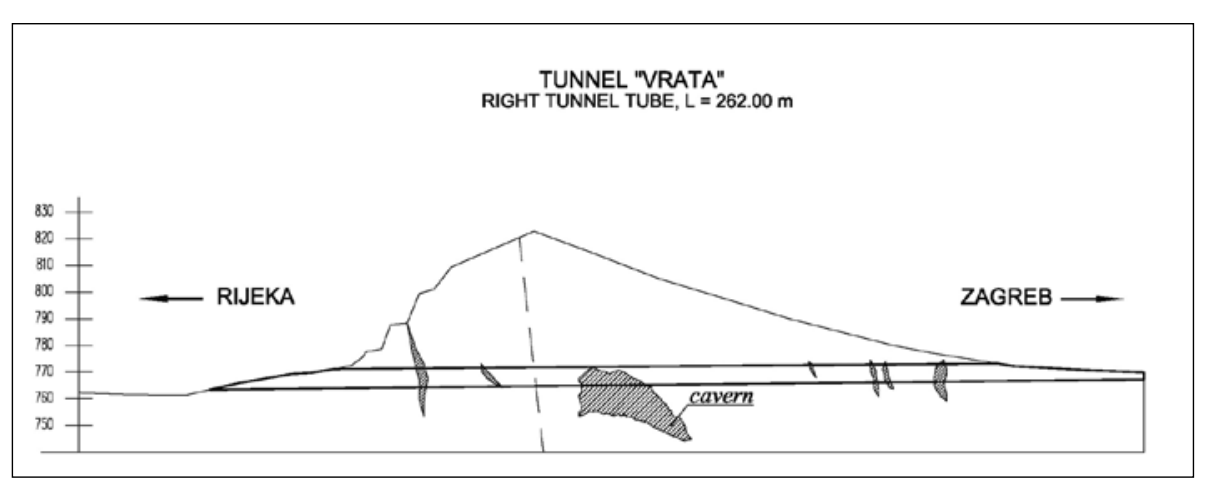

Fig. 3: Longitudinal section of the "Vrata" tunnel with intercepted caverns and voids. cavern's vault, and the bridging of the big cavern while paying attention to the tunnel's safety and ecological conditions, particularly groundwaters.

\section{Basic data on right tunnel tube}

Tunnel (RTT - right tunnel tube) where the cavern was discovered features the following:

- tunnel heading $\mathrm{km} 31+168$, final $\mathrm{km} 31+430$,

- entrance level line: $763.626 \mathrm{~m}$,

- exit level line: $765.876 \mathrm{~m}$,

- largest overburden: around $52 \mathrm{~m}$,

- level line's longitudinal gradient: $-0.9 \%$,

- excavation's cross section: $74.65-86.77 \mathrm{~m}^{2}$,

- cross section of the $56.17 \mathrm{~m}^{2}$,

- traffic line's width: $2 \mathrm{x}$ $3.50 \mathrm{~m}$,

- distance between two tunnel tubes: $15-20 \mathrm{~m}$.

The discovery of the speleological object (cavern) took place in the "Vrata" tunnel's right tube on the RijekaZagreb highway from $\mathrm{km}$ $31+257.00$ to $\mathrm{km} 31+307.50$ (Fig. 3).

\section{INVESTIGATION WORKS}

The investigation programme was created on the basis of location's inspection involving eight boreholes. Drilling was carried out by means of a motor drilling rig with continuous coring and rock sampling. No groundwaters were found during terrain investigation works in the drillings.

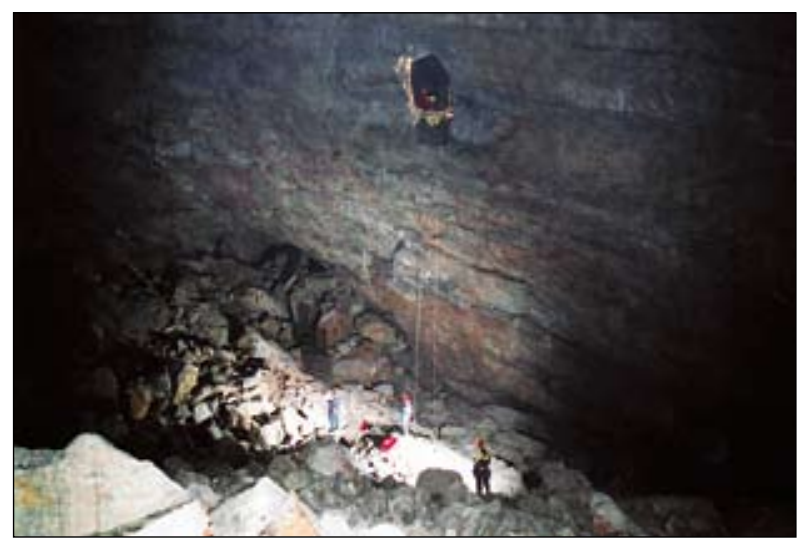

Fig. 4: The entrance from cavern to tunnel (Photo: M. Garašić).
Engineering geological, hydrogeological and speleological works were carried out in the cavern of the "Vrata" tunnel.

The works encompassed detailed speleological investigations and precise recordings, developing of detailed panoramic photos and video recording of complete cavern's vault which served for detailed engineering and geological map of the cavern's vault.

The investigation was carried out in autumn, during rainy and sunny days, when the air temperature on the surface varied from $+10^{\circ}$ to $+22^{\circ} \mathrm{C}$, whereas in the deeper cavern layers it ranged from $+8.8^{\circ}$ to $+9.0^{\circ} \mathrm{C}$.

\section{Position and dimensions of the cave entrance}

The $1.70 \times 2.25 \mathrm{~m}$ entrance into the cavern was made through blasting in the tunnel on $15^{\text {th }}$ September 2006. The word cavern is here used for voids having no access from the terrain's surface. The entrance was of irregular, rectangular shape. It was the cavern's entrance on the right (south-eastern) tunnel's side looking towards the 
tunnel's heading drilled in direction of Rijeka. A couple of days later, that is, on $21^{\text {th }}$ September 2006 the entrance got enlarged through blasting to $4.35 \times 3.20$ meters, obtaining thus an irregular and elliptic shape. The entrance is located in the "Vrata" tunnel on $\mathrm{km} 31+292$ on altitude 764 m (Fig. 4).

Some fifty meters north from the entrance into the "Vrata" tunnel there is the active Vratarka sinkhole, a temporary karst swallow hole collecting water from the Vrata karst field. The swallow hole had been explored from 1985 to 1992.456 meters of cave passages ending in a final sump have been documented so far. The connection with the source Potkoš in the Lič field (Zanoškar \& Garašić 1992) was confirmed by groundwater tracing.

The results of previous speleological investigations in the Preradović hill, crossed by the "Vrata" two tube tunnel, and $380 \mathrm{~m}$ long Vrelo cave in the same hydrogeological system lead to the assumption that the cavern drilled in the "Vrata" tunnel at $\mathrm{km} 31+292$ represents a part of a large speleological system. It has the role of groundwater transportation from the Vrata karst field towards the Lič karst field.

\section{Lithostratigraphy, tectonics and engineering geology}

The rocks in which the cavern occurs belong to upper Triassic dolostones (T3), with layers' thickness varying from 15 to $75 \mathrm{~cm}$. Dolostones are of bright to dark grey colour, and somewhere between layers there are brown thin interlayers of calcite bond. In the vicinity of and in the cavern itself the inclination of dolostone layers ranges between $15^{\circ}$ and $20^{\circ}$, and their inclination is directed toward the south and southwest (from $180^{\circ}$ to $225^{\circ}$ ). More intensive fractures and 3 to $4 \mathrm{~m}$ wide faults are to be found inside of the cavern. With lithological and hydrogeological conditions they take an important place in the genesis of the investigated cavern. No milonite fault's zones were observed in the cavern. The speleological investigation considers these faults to be relatively young, but at the moment inactive, which is proved by thin deposits of crystalline calcium carbonate covering the free fault's paraclase, particularly in the cavern's upper parts, without being broken or deformed. Dominant $20^{\circ}-200^{\circ}$ strike fault is very steep, nearly vertical paraclase (around $88^{\circ}$ towards south-eastern side). A completely vertical fault line with $105^{\circ}-285^{\circ}$ strike was observed. There is a very intensive corrosion of surrounding rocks, nevertheless lower than in pure limestone. It is highly probable that dolostones pass in their upper part into dolomitic limestone. Pure limestone and dolomitic limestone could be expected closer to reverse thrusting contact with Paleozoic layers, and towards Potkoš area in the Lič field. Edges and underground karrens, dimensions from 1 to $5 \mathrm{~cm}$ are very sharp.
Those are late diagenetic dolostones, crystallised, made of mosaic like arranged dolomite grains full of calcite inclusions with some clayey and limonite substance. The fossil remains within the rock are not noticed in the cavern.

Upper, steeper part of the cavern is of so called vertical or pit like shape with larger cross sections, followed by fault and fracture lines stretching east-west $\left(105^{\circ}-\right.$ $\left.285^{\circ}\right)$. Lower, more inclined or more sloping parts of the cavern (horizontal or cave like form) follow the main fault $\left(20^{\circ}-200^{\circ}\right)$, so as to the fault and fracture system stretching east-west would again play a dominant role at the lowest parts of the cavern (under the second tunnel tube). Initial water, which is important in the speleogenesis of this structure sinks through the surface fractures, (of which some have been backfilled with clay due to subsequent processes) which have been widened to present dimensions by water corrosion and erosion activities. These processes are still under way so that along the entire cavern periodically runs a stream carrying off the material from the cavern.

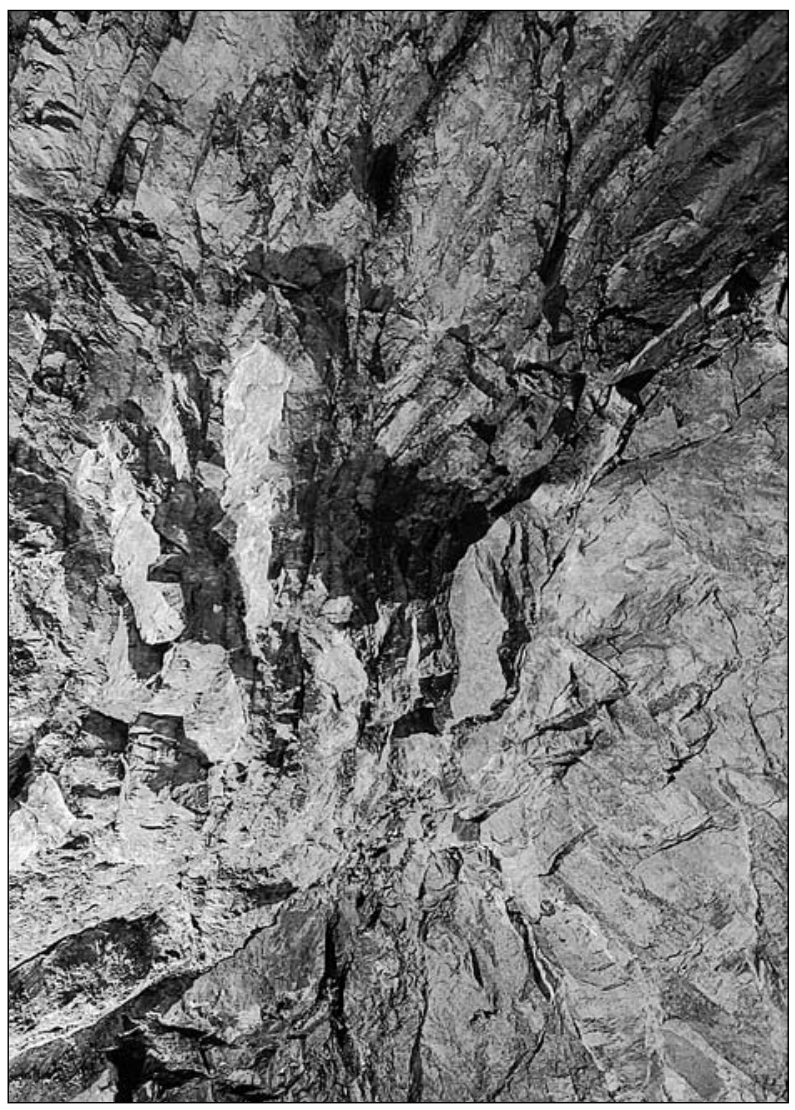

Fig. 5: Photo as base for engineering geology mapping (Photo: $M$. Garašić).

This speleological site shows signs of gravitation type karstification in upper parts, while in the lower 


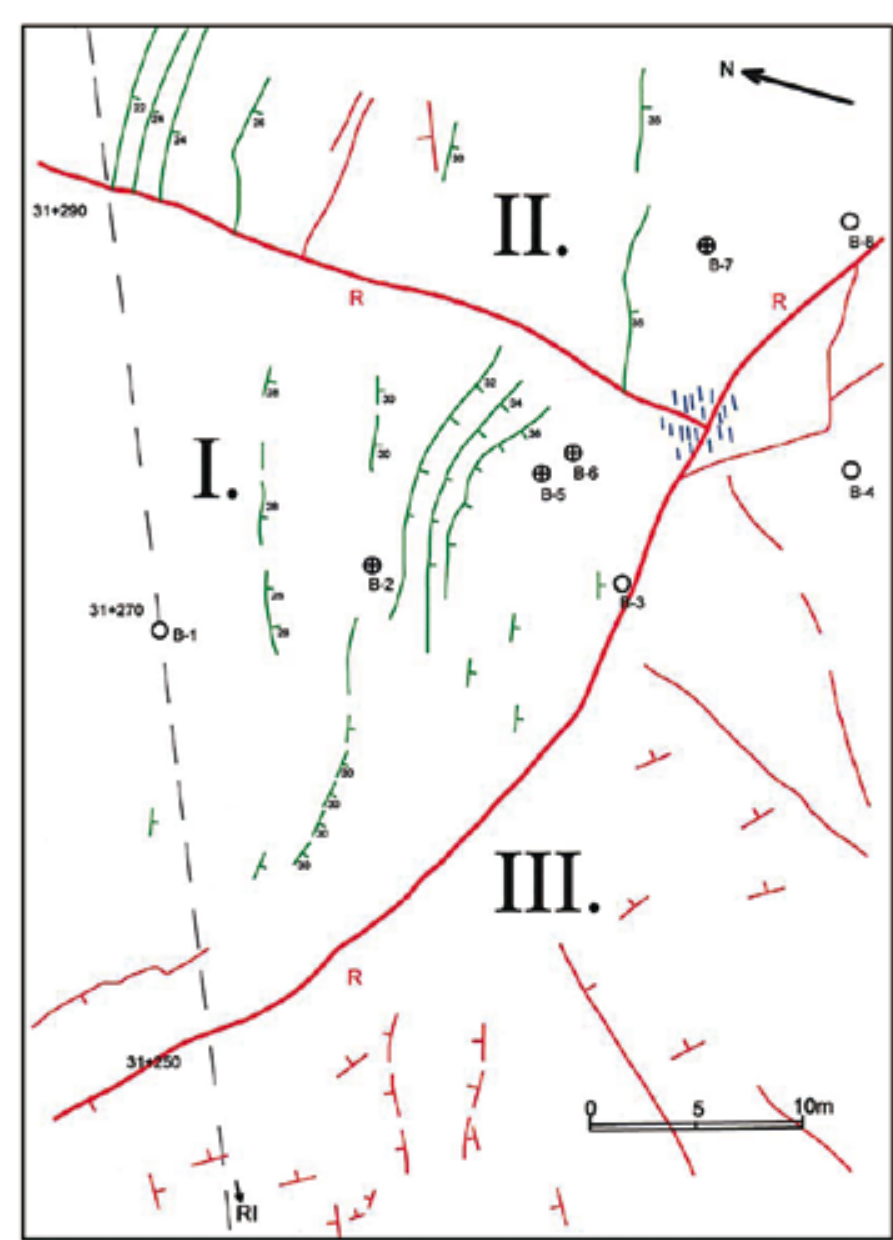

\section{Legend:}

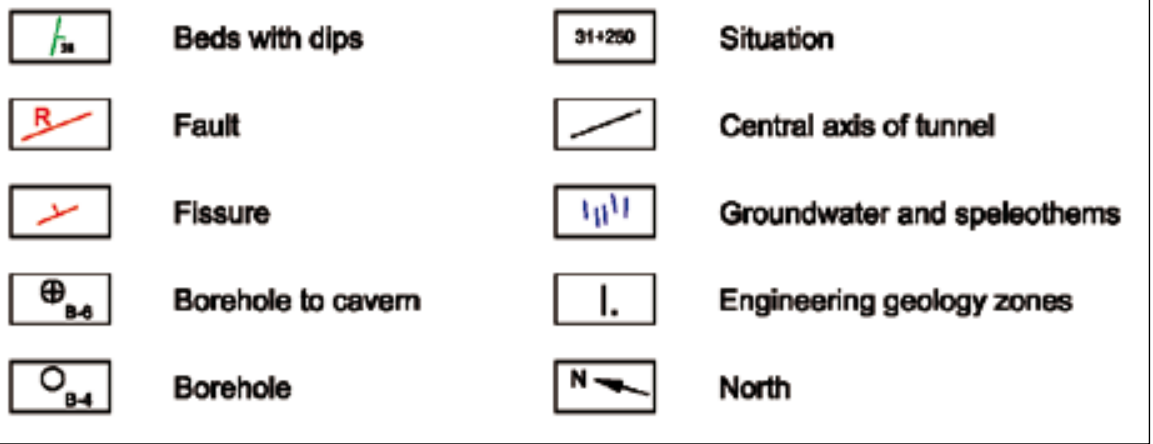

Fig. 6: Engineering geology map of cavern (the same position as photo on fig. 5). which intensive air current $(\mathrm{c}=1.3 \mathrm{~m} / \mathrm{s})$ has been measured, which proves a certain connection with another, still unknown underground space. The temperature differences between the upper part of the cavern $\left(+8.8^{\circ}\right.$ to $+9.0^{\circ} \mathrm{C}$ ) and the lower part of the cavern $\left(+7.5^{\circ} \mathrm{C}\right)$ indicate a possible presence of permanent groundwater.

As refers to UpperTriassic dolomites, calcareous dolomites and dolomite limestone and calcareous rocks it may be stated in engineering and geological terms that: uniaxial stratum compressive strength (limestone in the cavern level) amounts to 80-120 $\mathrm{MPa}$, Rock Quality Designation (RQD) is different, but mostly over $50 \%$, the average distance between discontinuity is approximately $50 \mathrm{~cm}$, and in the parts towards the surface with a clay filling. The tunnel level line amounts to approx. 30 meters under the terrain surface. The fissure systems reach lengths of over 20 meters, averagely 10 to 15 meters. Joint aperture varies from 0.1 to $1 \mathrm{~mm}$, the fissures in the upper parts of the cavern are rough and corrugated, whereas in the lower part they are smooth.

According to the Rock Mass (RMR) classification, rocks in which the cave was formed may be classified as a good stone mass (III class), and partially into the IV class (near fracture zones and spe- parts there are traces of regressive type karstification, i.e. aggressive progress towards the surface. In the cavern ceiling, corrosive forms and erosion recesses and current flutes have been noticed. The site dimensions may even be larger, but the further passage for speleologists has been obstructed by collapsed and unstable blocks, through leological sites). In the immediate vicinity of the speleological site (in the tunnel, 25 meters in the direction of Zagreb), a fracture zone was found filled with a clay material (Figs. 5, 6). 


\section{Speleomorphology}

According to the existing acknowledged speleological site classification (Garašić 1989, 1991, 1993) the cavern at $\mathrm{km} 31+292$ is a vertical speleological site (pit), of step-like which is partially backfilled in its lower part.

The microclimate within the cavern was changed along with the change of the entrance size. Namely, much warmer air from the tunnel started entering the cavern, thus reducing relative air humidity and heating the rocks which consequently started expanding. The stone "expansion" resulted in collapse of unstable stone blocks from the cavern ceiling. Lower parts of the cavern still remain in the same conditions (temperature, humidity). Their possible instability may be caused by blasting in both left and right tunnel tube, at times when the blasting measurements showed minor seismic activities. Cutting the entrance from the Rijeka side of the tunnel is expected to cause another change of micro-climate within the cavern. However, due to lower temperatures in winter, the temperature in the tunnel shall be much lower and much closer to the mean annual temperature of the area, or the air temperature in the cavern. The balance is expected to be reached after the spring period, when the stone block collapse from the cavern ceiling should be much less frequent.

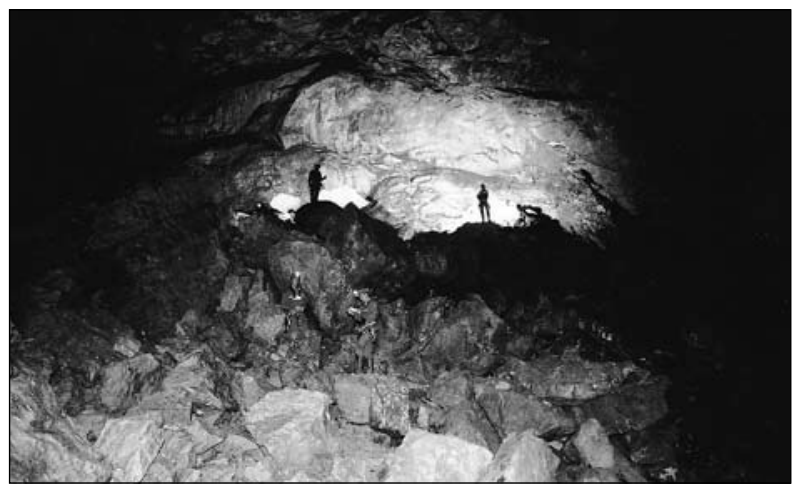

Fig. 7a: Big chamber with place of tunnel west entrance (Photo: M. Garašić).

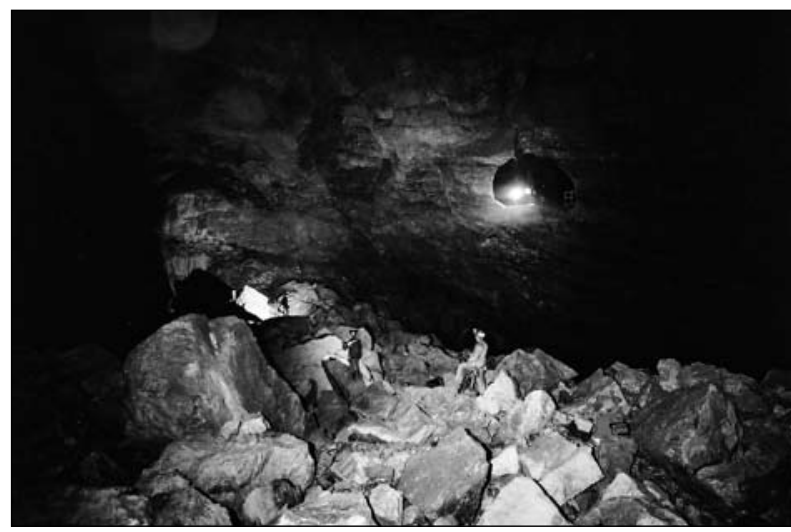

Fig. 7c: Place of bridge (Photo: M. Garašić).
The entrance is of irregular elliptical form and vertical on all sides, with overhangs. A drop fall, one step vertical shaft leading to the lowest point at the time of the first descent was 16.65 meters, but its current depth due to the blasting and the new material dropped into the cavern amounts to 15.20 meters. In this case it is a caved-in type of entrance into the pit. Next follows the debris cone spreading to all directions of the big hall but generally falls toward the north (Fig. 7).

The simplified description of the explored part of the cavern may be given as a large hall, the bottom of which is filled with large blocks and debris cone material, and inclined towards the north. In its southern part, the hall is higher (20 meter high), and in the northern part which ends in a cave channel, between 5 and 10 meters high. The difference in height between the debris cone top at the southern side and the lowest parts in the northern cave channel exceeds 20 meters. The difference in height between the highest parts of the cavern ceiling and the bottom at the cave channel exceeds 37 meters. The hall profile from the debris cone top to the lowest point under the left, northern tunnel tube is 66 meter long in its horizontal projection (73 meters in polygon projection). The longest hall profile which is parallel with

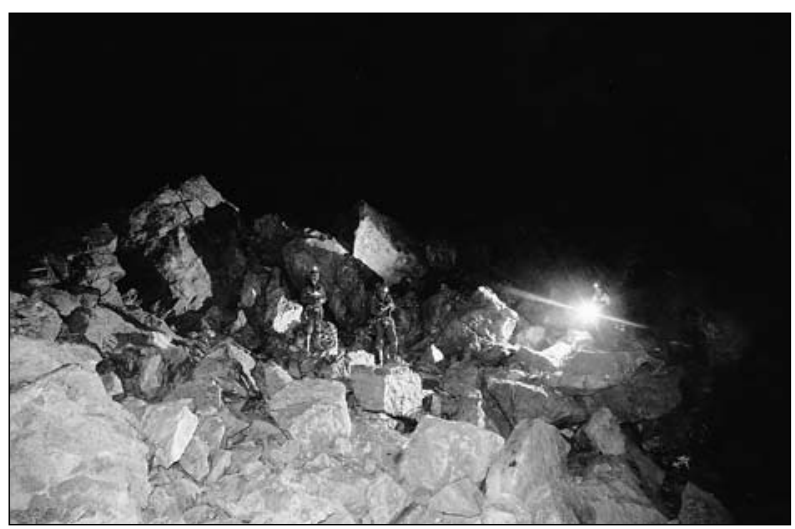

Fig. 7b: Floor of the cavern (Photo: M. Garašić).

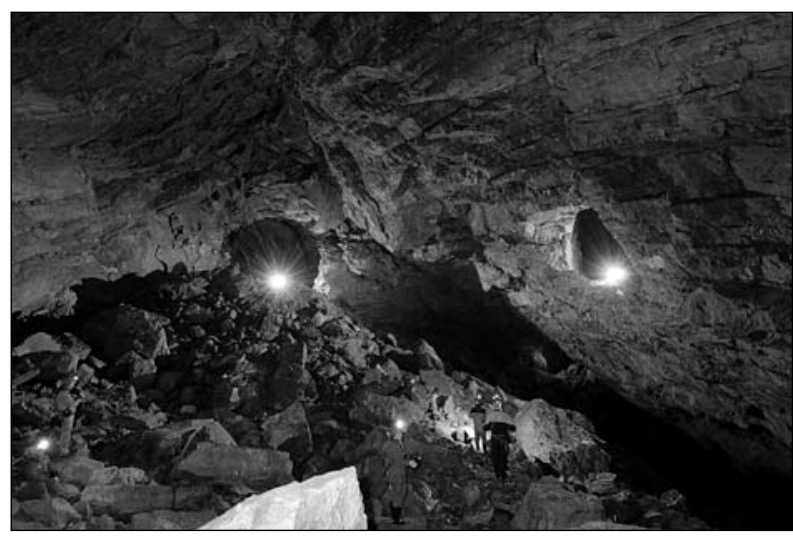

Fig. 7d: Two entrances of tunnel in cavern (Photo: M. Garašić). 
the tunnel is 51 meters long in horizontal projection (57 meters in polygon projection, Fig. 8).

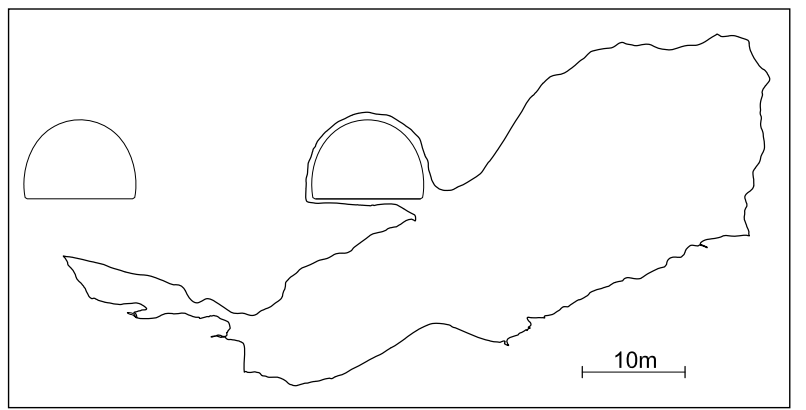

Fig. 8: Profile of the cavern.

Between the Zagreb and Rijeka tunnel entrances into the cavern, the distance between 32 and 35 meters along the tunnel centerline is planned, depending on the rocks break off during cutting through the tunnel from the Rijeka side.

Debris cone in the hall may represent the so called "false bottom" from which the air can be felt streaming in the ending northern part in the direction of the ca- vern. Air current is measured by a digital anemometer $(\mathrm{c}=1.3 \mathrm{~m} / \mathrm{s})$, on the profile of $\mathrm{P}=5.6 \mathrm{~m}^{2}$ surface, which indicates the large spaces and air quantities $\left(\mathrm{Q}=7.28 \mathrm{~m}^{3} / \mathrm{s}\right)$ entering the cavern. In the northern parts of the cavern situated under the right tunnel tube, vehicles in the tunnel can be heard. Measurements have shown that it is due to about 5 to 6 meters of the overburden between the tunnel lining and the ceiling of the passed cavern part. No newly created joints or damages to the cavern ceiling have been noticed. In the northbound cave channel, unstable stone blocks prevented further passage of the speleologists between the fractures. Speleothems are a very rare phenomenon in this cavern, but there are corrosion types of subterranean flutes suggesting intensive activities of ground water.

Topographic survey of the site has been made by both optic and laser instruments (Magellan, Leica and Suunto), with the precision of $\pm 0.1^{\circ}$ (Fig. 9). The total volume of this speleological site is estimated to about 50,000 to $55,000 \mathrm{~m}^{3}$. However, it is possible that the cavern and the cave channel continue even further along the paraclase, along the narrow and backfilled fractures under the debris cone material.

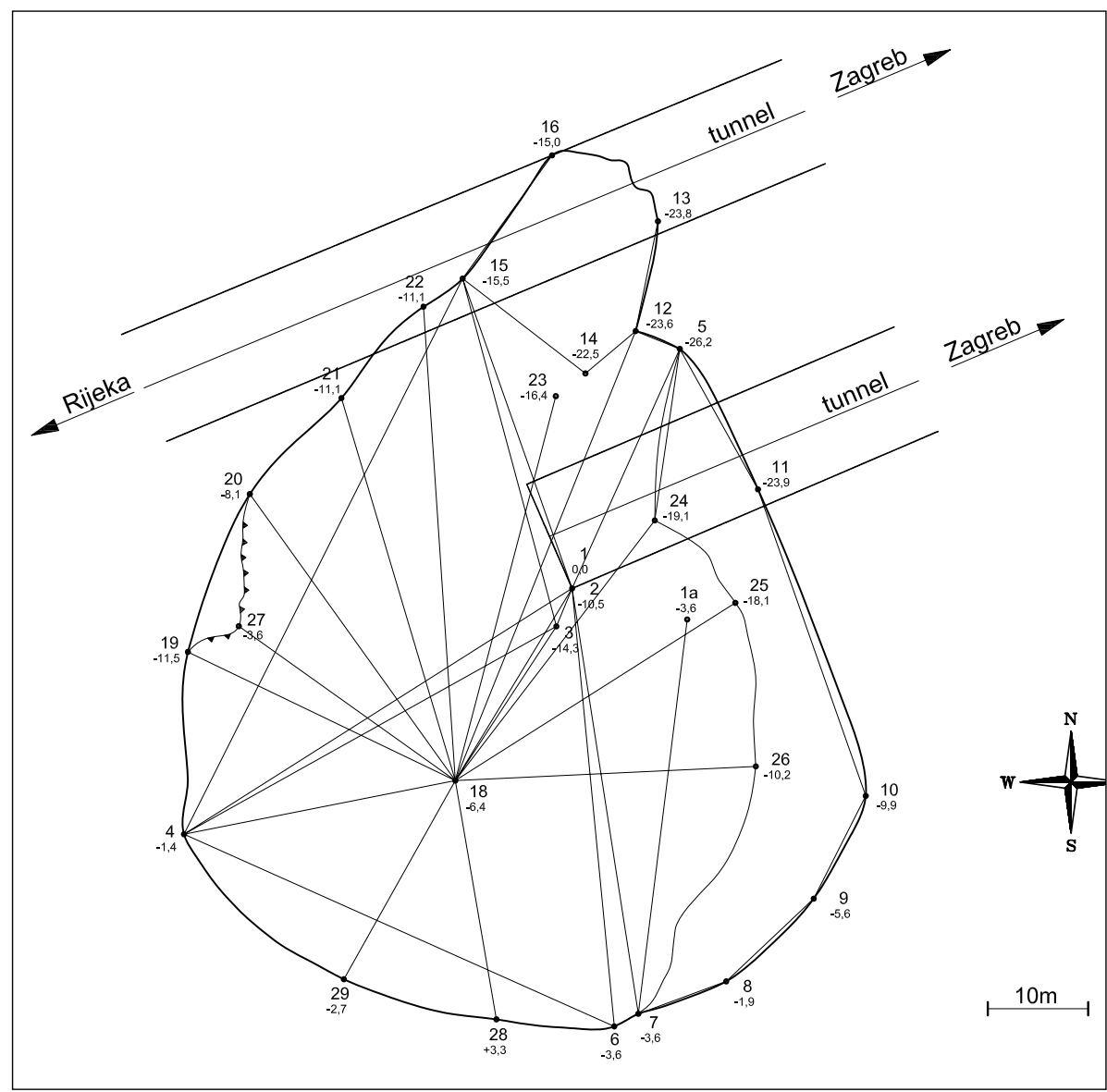

Fig. 9: Plan of cavern with tunnels.

\section{Site hydrogeology}

From the hydro-geological point of view, it can be stated that there are occasional active ground streams in this speleological structure. Dripping water is also present, which even today has intensive chemical action to the surrounding rocks (corrosion), which results in forming of undergroung karrens. Only a small part of the cavern is covered with speleothems (dripstone formations). Regarding the paleohydrogeological function of the site, there was an occasional surface sinking stream pit, the entrance of which was caved-in most likely in the present time, and a part of the cave channel belonged to the sinkhole of the Vratarka sinking stream. For the time being, the impassable lower, northern parts of the cavern could be connected to the speleological system of the 
Vratarka sinkhole, the entrance of which is about $50 \mathrm{~m}$ to the north from the Zagreb entrance into the "Vrata" tunnel. The sinkhole water must run somewhere under the tunnel since it exits at the Potkoš spring in Lič Polje, which is situated about $2 \mathrm{~km}$ to the south from the tunnel. Depth of karstification in the area of this speleological site is estimated to several hundred meters, while the zone of vertical circulation is about 50 to $100 \mathrm{~m}$. Next follows the zone of horizontal circulation, which transports the groundwater toward the Bajer Lake or Lič Polje (the Potkoš spring). The stratum contains impermeable Paleozoic sediments of clay schist. Since, in hydrogeological terms, the Triassic dolomites are still permeable due to intensive secondary (fracture) porosity, several similar structures may be expected in the extension of this fault zone. These structures cannot be accessed from the surface and are connected with the mentioned sinkhole at the Vrata tunnel.

\section{Speleogenesis}

This cavern was formed by widening of a paraclase and fractures close to the paraclase $20^{\circ}-200^{\circ}$ strike and the fault $105^{\circ}-285^{\circ}$ strike in intensively karstified UpperTriasic dolomites, calcareous dolostones and dolomitic limestone. The initial water, which is very important in the speleogenesis of this structure, was sinking through the surface fractures of the Preradović hill surface, widening them to their present dimensions by its corrosion and erosion actions. Lower part of the cavern was formed under the impact of water originating from the Vratarka sinkhole. These processes are still going on today. In the speleogenesis of this cavern, the role of water swallowed by the Vratarka sinkhole is also important. The minimum of 50,000 to $60,000 \mathrm{~m}^{3}$ of rock materials has been transported either in chemical or mechanical way from the rock massif to the Lič Polje area, which is a sufficient proof of intensity of karstification in this speleological structure.

\section{Speleological conclusion and proposals for cave rehabilitation}

The explored part of the speleological structure stretches under and on the right and left side of the tunnel tube, and represents a certain problem in respect to stability and rock strength of the future tunnel route (Fig. 10)

We hereby propose the designing engineer to solve the crossing over the cavern in such a way so as to avoid placing the structure foundations within the cavern, as there is a large possibility of "false bottom" occurrence. Debris cone is not stable nor is its depth known. Besides, the active groundwater stream runs under the debris cone.
In no way do we recommend partial or complete backfilling of the cavern with stone material or concrete, as it would cause disturbance in the underground streams, which would result in immeasurable consequences for the tunnel in a narrower sense and the environment in a wider sense. Anyway, lower parts of the cavern cannot be backfilled from the surface anyway, as it would leave uncontrolled voids within the rock fill or concrete. The function of passage and water sinking should be maintained in any case. At any rate, an opening in the tunnel should be designed to enable entrance, when necessary, into the cavern for periodical checking of the state of the structure and the cavern. The reinforcement of the cavern ceiling may be executed by grouting from the surface, which should be also executed in the existing left tunnel tube in the area where the cavern passes beneath the tunnel (distance of 5 to 6 meters, Fig. 11).

Further works or blasting may reveal more caverns of similar position on the same or parallel faults. In such cases, they should most certainly undergo speleological investigation, and their position in relation to the highway and other know speleological structures should be determined.

\section{Additional surveying in the cavern}

From additionally created map, joints and paraclase rock zones, more and less damaged, may be distinguished. For taking the stereo photographs of the cavern ceiling (about 200 points of shooting) photographic techniques with shift axes were used. The obtained material enables the measurement of individual fracture, block, etc., lengths.

Engineering and geological mapping and surveying are performed in the newly opened cavern in the right (south) «Vrata» tunnel tube between $\mathrm{km} 31+240$ and $\mathrm{km}$ $31+255$, on the Zagreb-Rijeka highway, Oštrovica-Vrata section, at Fužine in Gorski kotar, during December 2006 and January 2007.

\section{Photographing methods}

A 24 photo compilation ( $6 \times 4$ rows) taken in stereo and $3 \mathrm{D}$ technique was used for making panoramic photographs of the entire cavern ceiling. The stereo shooting base is set up to $45 \mathrm{~cm}$, thus intensifying the stereo or the spatial effect of the photo. Each photo was taken 12 times (for each stereo couple) in order to ensure the quality of taken material. In total, 288 photos of the cavern ceiling were taken, compiled and arranged in one final photograph, which served as a base for making the engineering geological map.

Both digital and analogous shooting techniques have been used with the "Linhof technika 45 " and "Wista $4 \times 5$ " cameras (large format cameras), "Rolleiflex 6008 


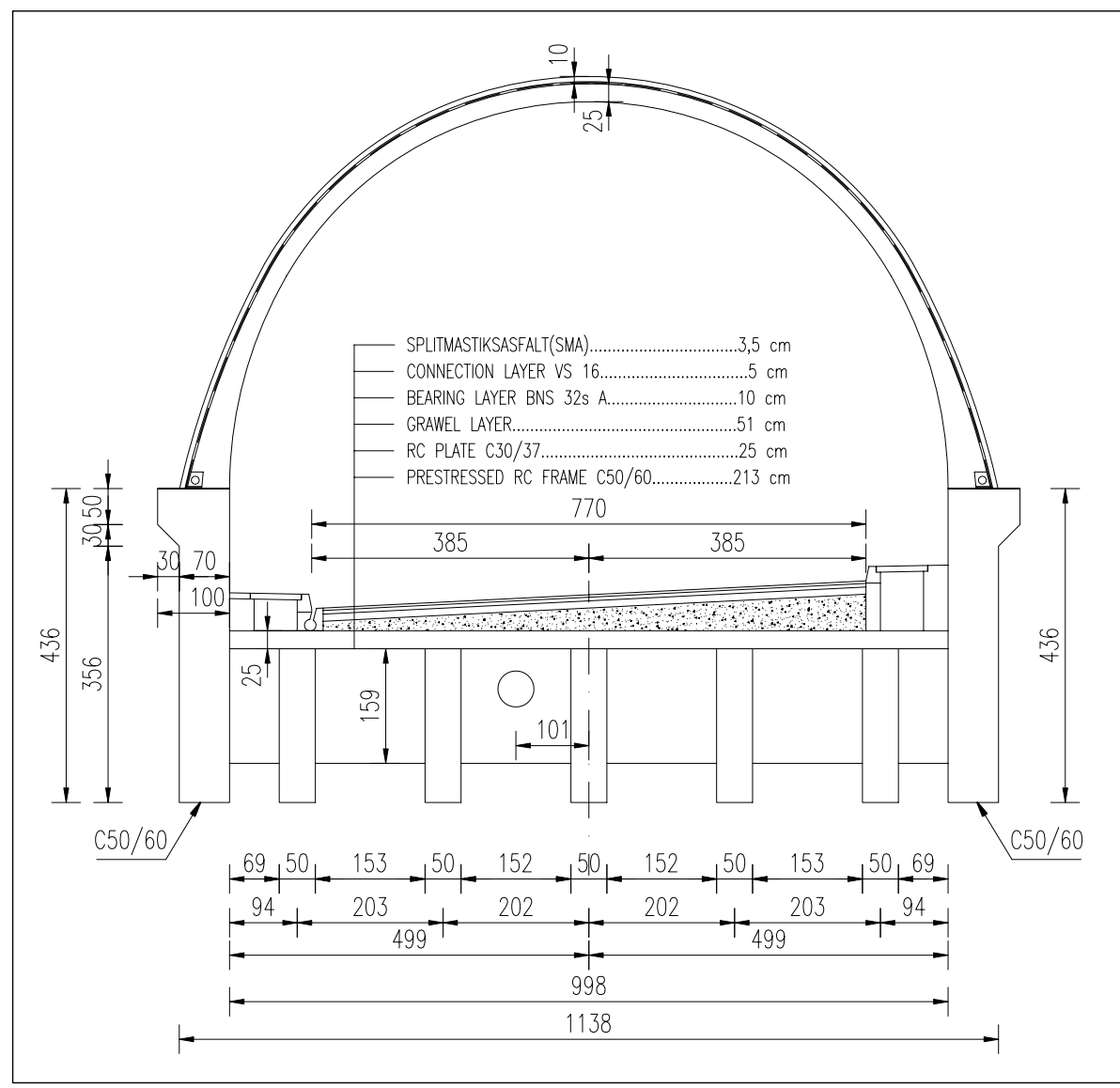

Fig. 10a: Cross section of bridge.

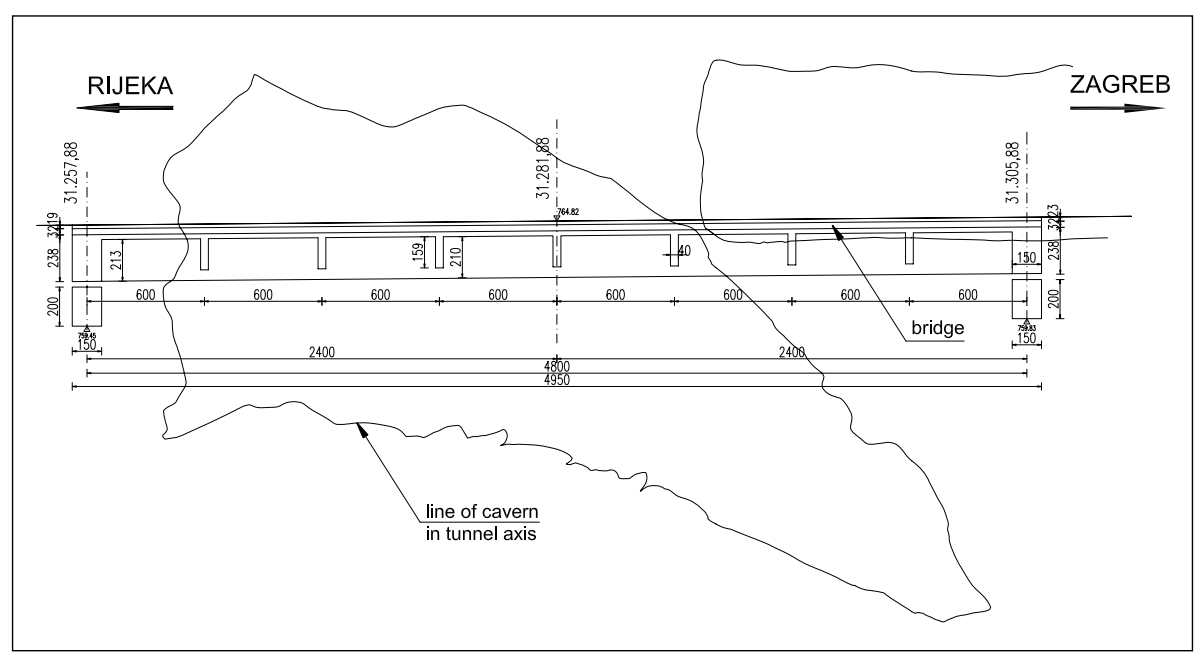

Fig. 10b: Longitudinal cross section of bridge.

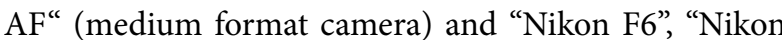
D2x" and "Nikon D3" (analog and digital small format cameras).

For lighting of large areas, 4 "Quantum 5td" electronic flashes have been used, 5 "Metz Mz 76-5" flashes and 5 "Nikon SB-800" flashes. The area in question is extremely large, and requires much light at a certain moment. Synchronization between the electronic flashes and photo cameras at such large distances has been achieved with about twenty "Pocket Wizard" radio slaves, "Multiblitz", "Wein" and "Quantum", as well as "Metz" and "Nikon" photo cells. The shooting points have been geodetically defined, and the control has been performed according to the boreholes drilled from the surface. "Leica" laser distance meters have also been used for the general triangulation purposes.

\section{Engineering geology map}

Engineering geological map has been created based on a $3 \mathrm{D}$ model of the complete cavern ceiling. Subsequently, a mirror figure of the ceiling has been made, so that the map represents a real state viewed from the terrain surface, and not from the cavern as it was shot.

Such actions were performed in compliance with the generally accepted recommendations for elaboration of engineering geological maps by the international geological federation.

Taking into consideration both planar and tectonic elements, their position, karstification intensity, joint aperture, filling, roughness etc., the cavern ceiling in the "Vrata" tunnel area may be divided into three different engineering geological unities.

The first unit (I) is located almost above the entire tunnel, and includes well bedded compact limestone. There are no special fissure systems except for the dominant interlayer cracks. In the cavern entrance from the 


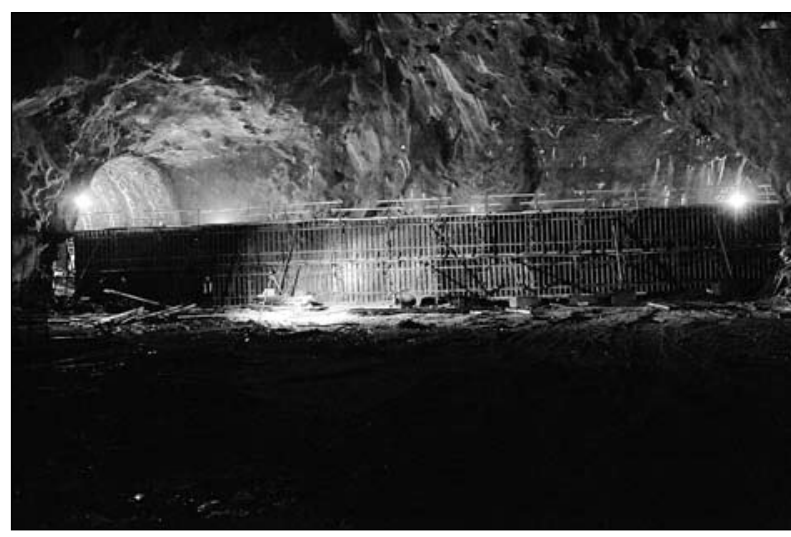

Fig. 11a: Constructing bridge in cavern (Photo: M. Garašić).

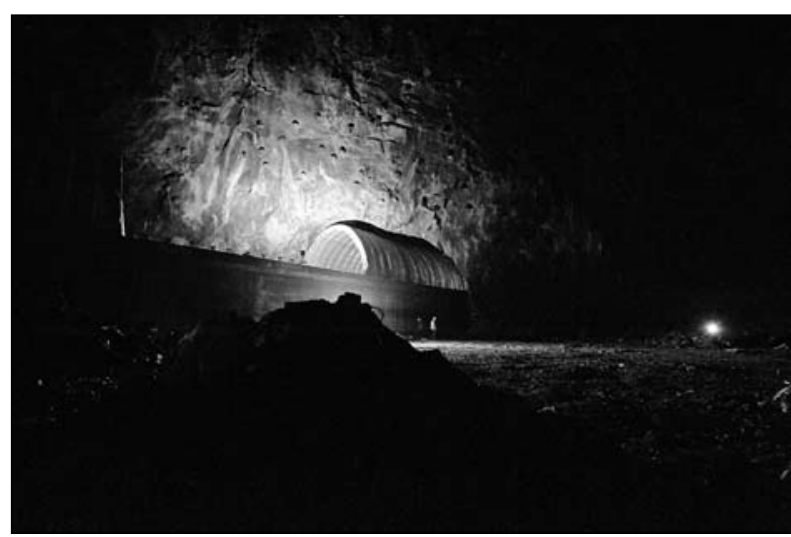

Fig. 11c: Cavern, tunnel, bridge and protecting ancors (Photo: $M$. Garašić).

Rijeka side the situation changes, as the engineering geological unit (III) with two fissure systems occurs. The area includes both southern and western part of the hall. The unit (II) area is located in the ending eastern part of the cavern ceiling, and is exposed to layer cracks by the occurrence of speleothems and cutting off (Figs. 5, 6).

These engineering geological units are separated by paraclases of a no longer active fault, which is proven by a speleothem occurrence at the intersection of two faults in the southeastern part of the ceiling.

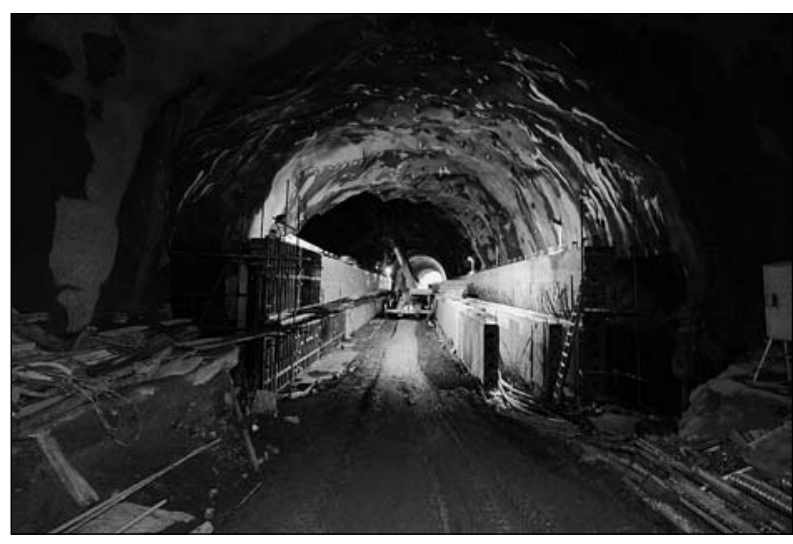

Fig. 11b: Bridge in tunnel (Photo: M. Garašić).

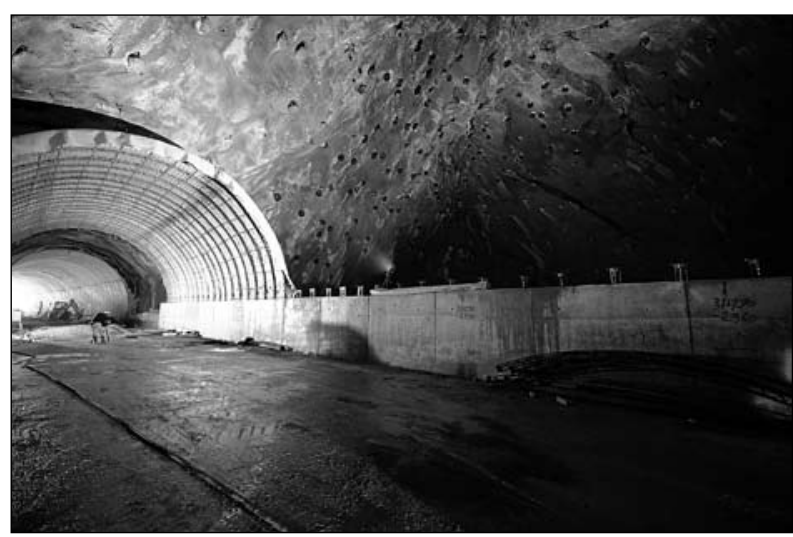

Fig. 11d: Final phase of constructing (Photo: M. Garašić).

\section{Determination of rock mass strength parameters}

The choice of rock mass strength parameters was made by taking into consideration engineering geologi$\mathrm{cal}$ and geotechnical terrain characteristics at the location under consideration, as established by field and laboratory exploration works.

The rock mass strength parameters have been calculated by the empirical Hoek \& Brown failure criterion for rock masses (general form; Hoek et al. 2002.), or the equivalent Mohr-Coulomb's criterion, based on uniaxial strength obtained by laboratory testing and the GSI - Geological Strength Index.

\section{SELECTION OF ROCK SUPPORT SYSTEM FOR SPELEOLOGICAL SITE CEILING STABILIZATION}

Based on the results of rock mass classification and performed numerical analyses, the selection of rock support system for the cavern ceiling stabilization has been selected.
The elements required for the cavern ceiling stabilization are as follows: grid structure to be executed on the cavern surface, tendons and geotechnical anchors. 


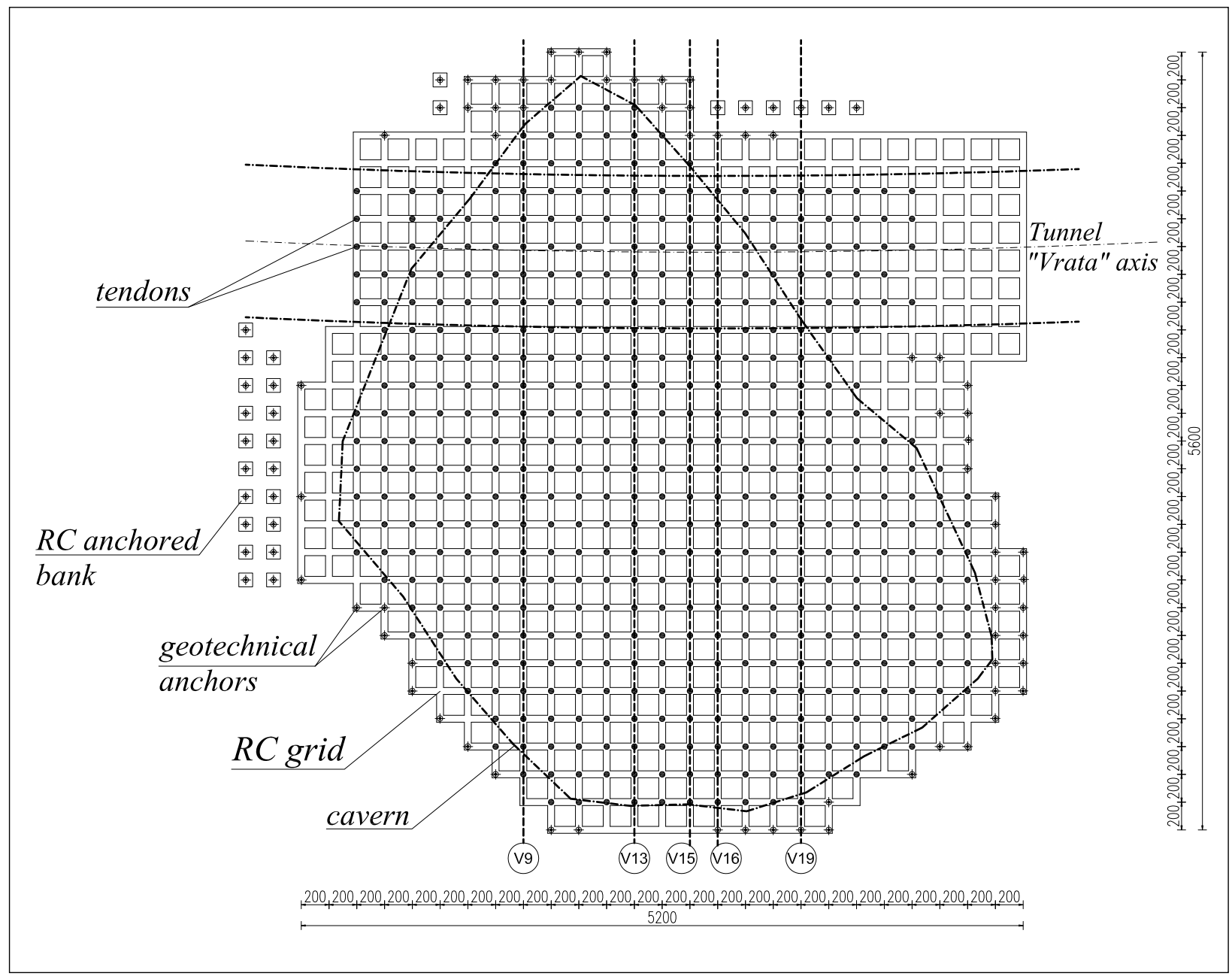

Fig. 12: Grid structure plan.

\section{Grid construction}

The grid construction shall be executed on the surface above the cavern (Figs. 12,13). The grid raster is $2 \mathrm{x}$ $2 \mathrm{~m}$, the grid height ranges from $1 \mathrm{~m}$ to $1.15 \mathrm{~m}$, while the width is $0.5 \mathrm{~m}$. The grid is to be reinforced by corrugated

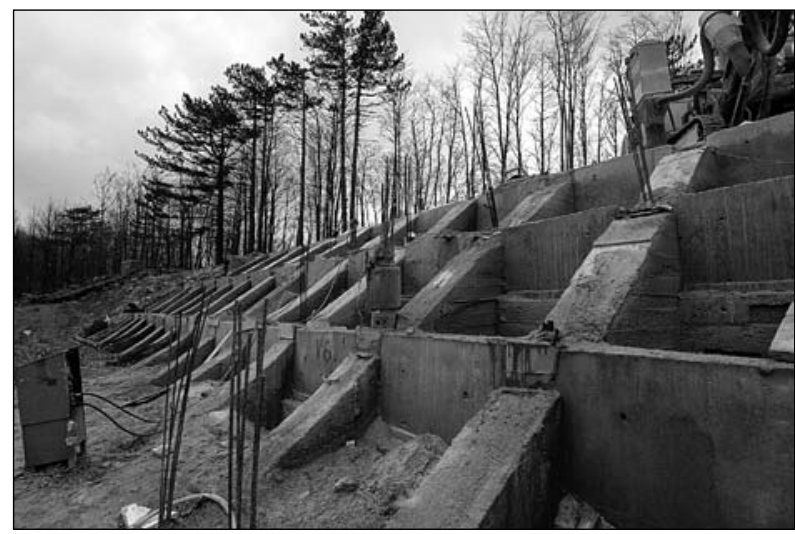

Fig. 13a: Grid at the surface (Photo: M. Garašić). reinforcement made of high-value natural hard steel of 400/500-2 quality. The concrete quality shall be C25/30.

Fig. 14a presents characteristic longitudinal and Fig. $14 \mathrm{~b}$ cross section of grid construction at the terrain surface.

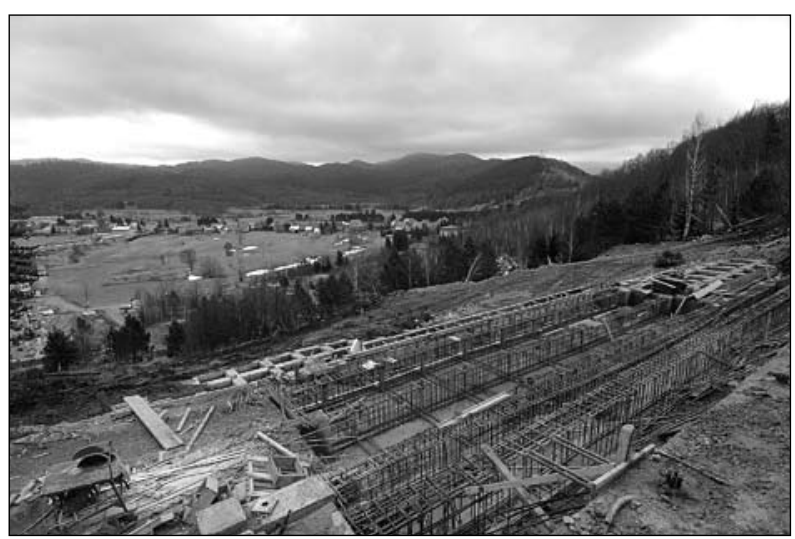

Fig. 13b: Constructing grid (Photo: M. Garašić). 


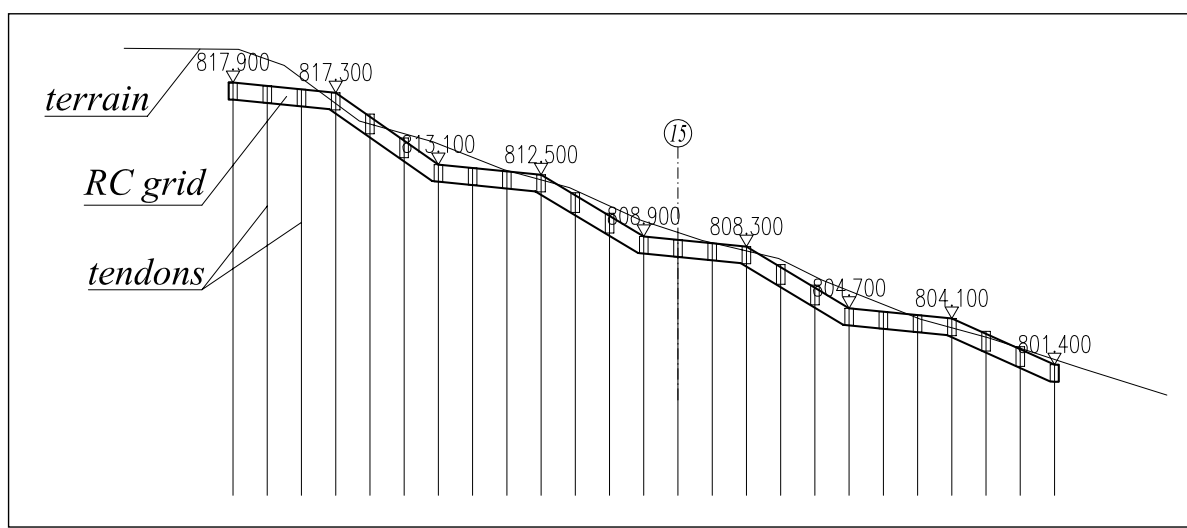

Fig. 14a: Grid structure longitudinal section.

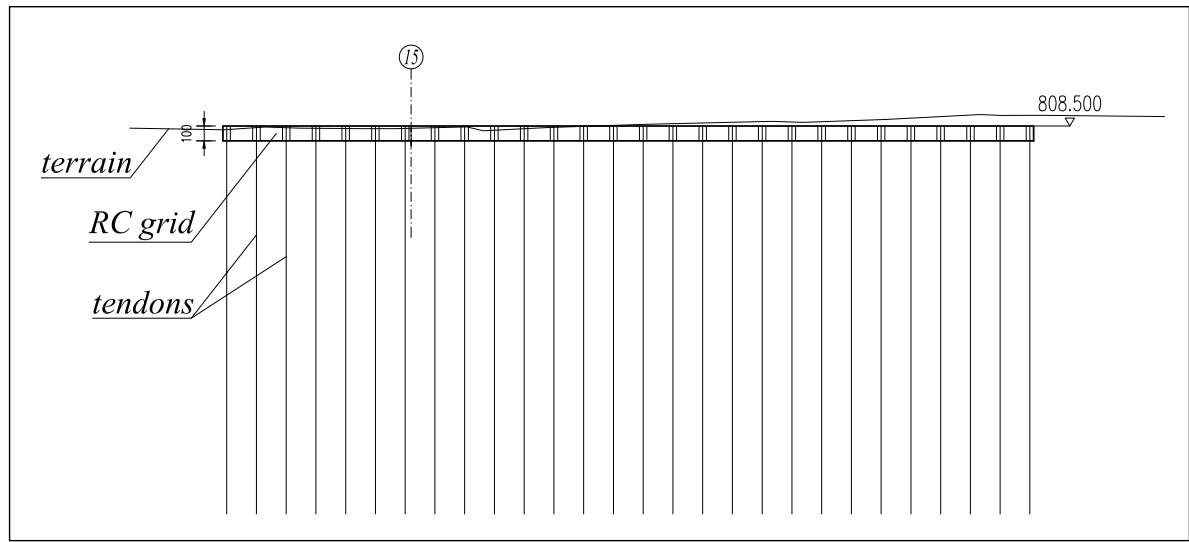

Fig. 14b: Grid structure cross-section.

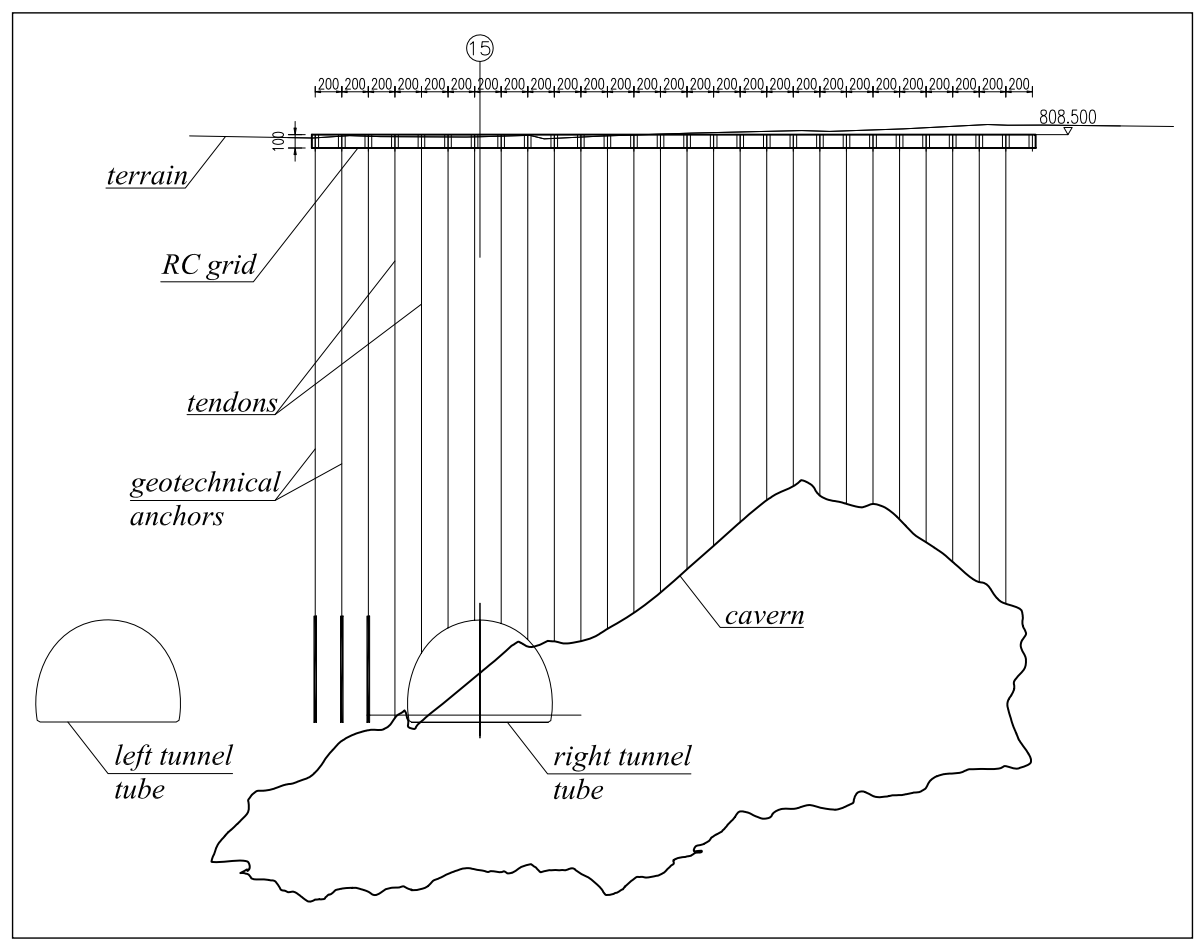

Fig. 15: Tendons and geotechnical anchors cross section V15.

\section{Tendons}

The anchors type VBF07-140P shall be used for upper and lower cable anchors for prestressing. The prestressing cables shall comprise 6 ropes of diameter Ø0.6”, $A=1.4 \mathrm{~cm}^{2}$. The average cable's length amounts to $37.6 \mathrm{~m}$. Steel quality shall be 6 fracture $>1860 \mathrm{Mpa}$.

The upper anchor heads shall be protected by concreting into the concrete block dimensions $50 \mathrm{~cm} \mathrm{x}$ $50 \mathrm{~cm} \times 20 \mathrm{~cm}$. The concrete quality shall be $\mathrm{C} 30 / 37$. The lower anchor head shall be protected so that a tin cap is being fixed to the anchor steel plate, while the space between the cap and the anchor is to be grouted with grouting material.

The tie tendon prestressing was executed as follows: tendon prestressing at $800 \mathrm{kN}$, detensioning at $100 \mathrm{kN}$, and retensioning at $500 \mathrm{kN}$.

\section{Geotechical anchors}

The BBR CONA SOL type 706 (5Ø0.6") geotechnical anchors shall be installed of $1395 \mathrm{kN}$ breaking strength. The boreholes provided for geotechnical anchors shall have $\varnothing 150 \mathrm{~mm}$ diameter. The average borehole length shall amount to $44.7 \mathrm{~m}$. The anchor heads shall be filled covered with fine grained concrete C30/37.

The anchor prestressing was executed as follows: prestressing at $800 \mathrm{kN}$, detensioning at $100 \mathrm{kN}$, and retensioning at $500 \mathrm{kN}$.

Fig. 15 presents characteristic tendon and geotechnical anchor cross section. 


\section{NUMERICAL ANALYSIS OF PROVIDING THE VAULT STABILITY OF THE SPELEOLOGICAL OBJECT}

After defining the support system the ultimate analysis of the stability of speleological object was performed assuming the possibility of various scenarios referring to the complete loss of rock mass strength that causes the widening of the speleological object, i.e. the fracture of rock mass. In such case the ties and geotechnical anchors secure the stability of rock mass with satisfactory safety factors.

Fig. 16 (a-d) presents the results of the safety factor calculation for various stability loss scenarios referring to the vault of the speleological object in a characteristic cross-sections.
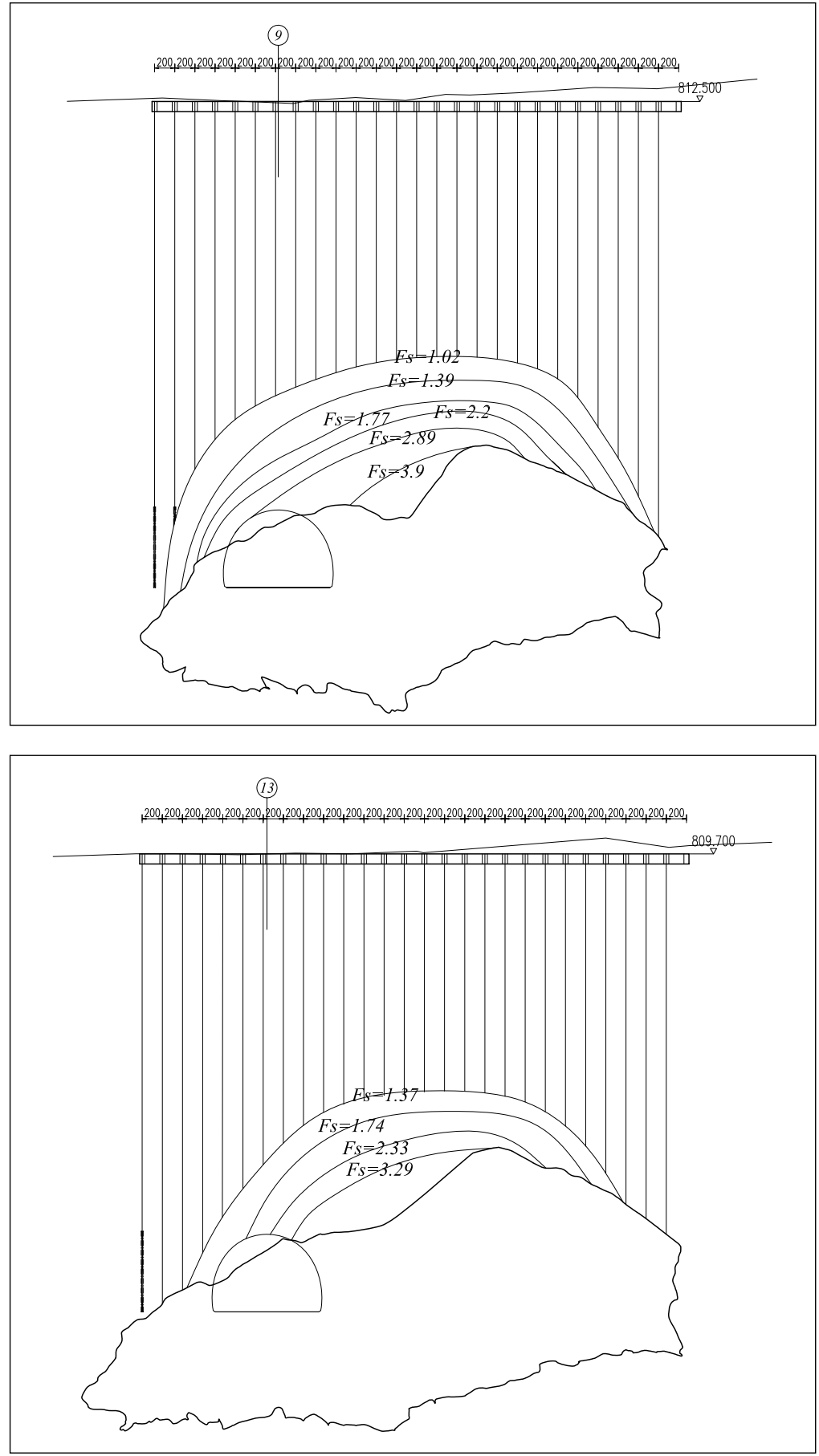

Fig. 16a: Safety factors in stability loss for the cross-section V9.
Fig. 16b: Safety factors in stability loss for the cross-section V13. 

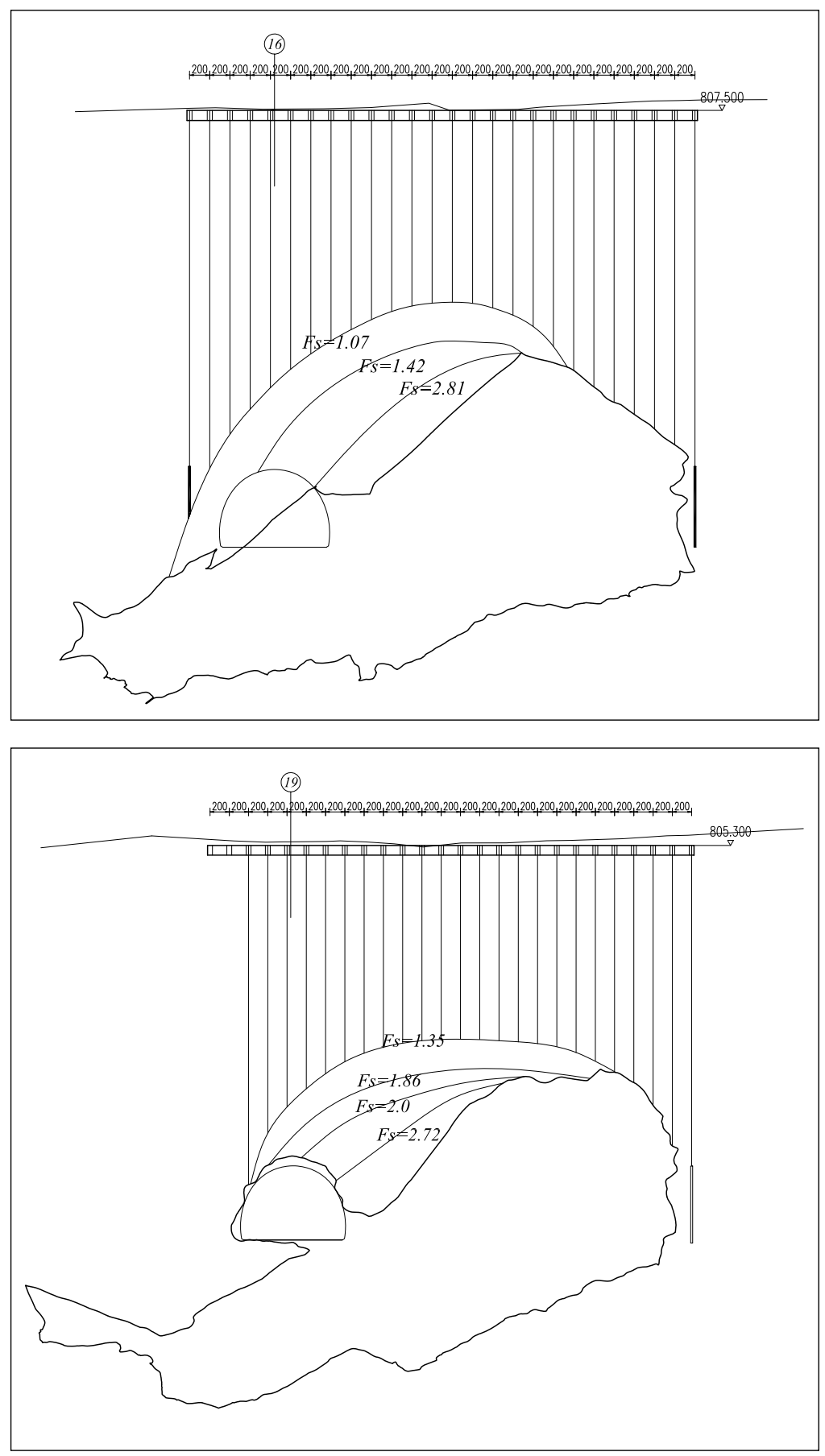

Fig. 16c: Safety factors in stability loss for the cross-section V16.

Fig.16d: Safety factors in stability loss for the cross-section V19.

\section{GEOTECHNICAL MEASUREMENTS AND OBSERVATIONS}

Geotechnical measurements in combination with backward numerical analyses present a fundamental part of the interactive design concept (Kovačević 2003; Kovačević et al. 2005; Kovačević et al. 2006) or of the
$\mathrm{II}^{\text {nd }}$ design phase as interactive design is called in Croatia tunnel practice.

Numerical analyses in which material parameters are changed in accordance with the results of geotech- 


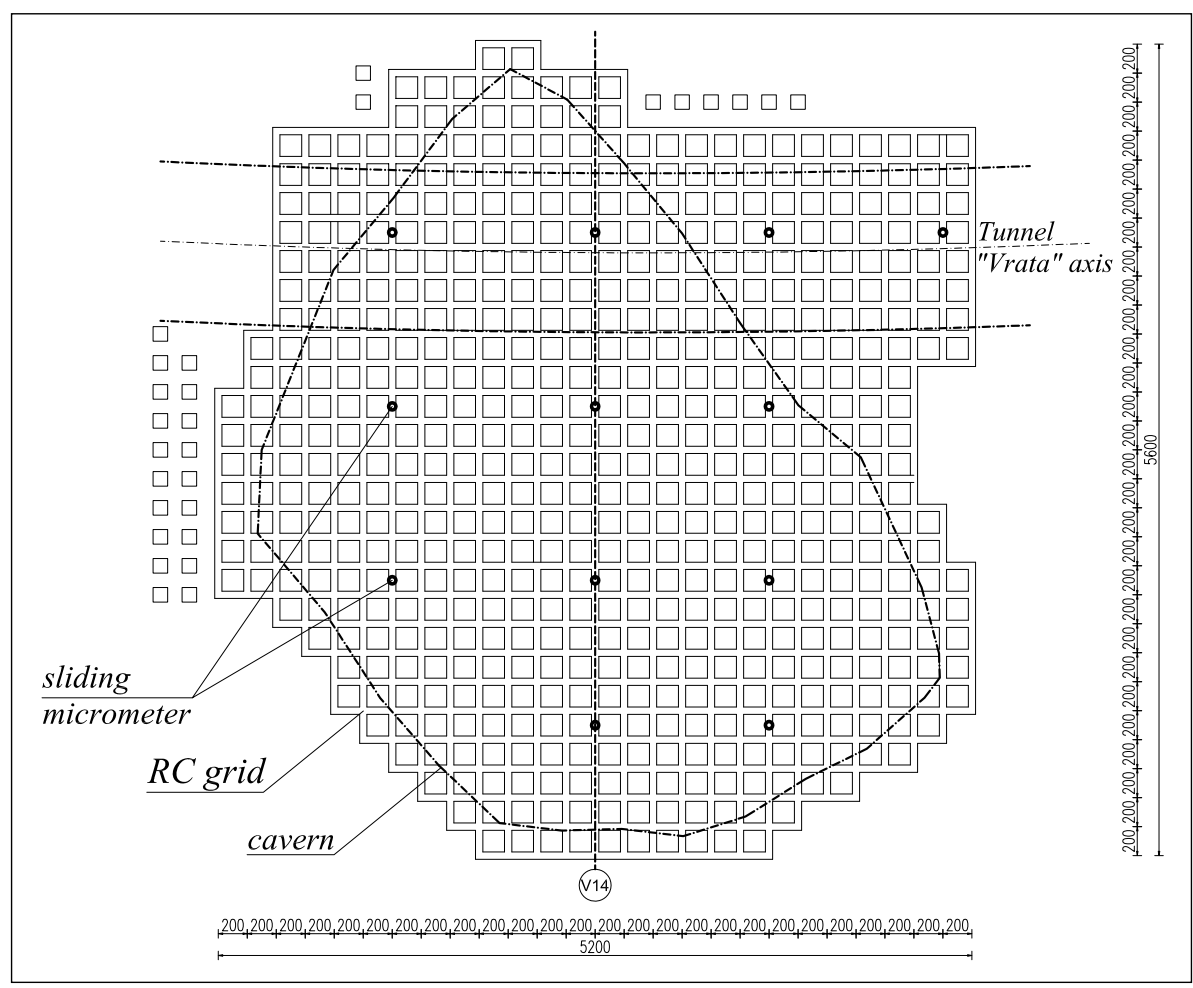

Fig.17: Sliding micrometers disposition in plan.

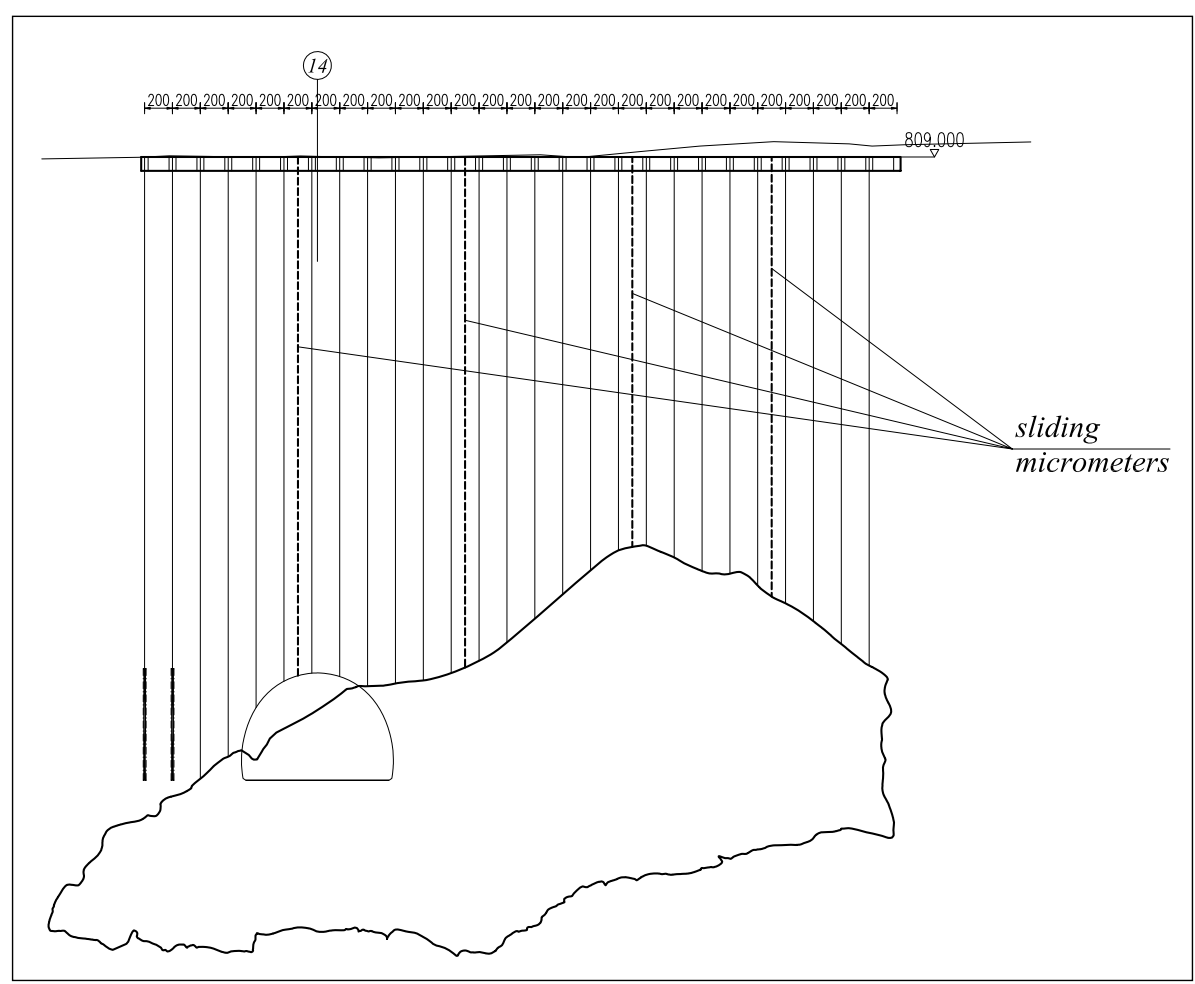

Fig. 18: Sliding micrometers for the cross-section V14.

nical measurements and observations are called return analyses in the professional language. The principle of backward analyses is to calculate the state of stress and deformations for the presumed material characteristics, and the calculated state is then to be compared with the measured situation in the field. Since the calculation results do not agree with the measurements in most cases, the material characteristics need to be changed until the calculated and measured values become congruent with the accuracy that is satisfactory in engineering terms.

Available calculation methods in geotechnics, linear and nonlinear constitution equations, $2 \mathrm{D}$ and $3 \mathrm{D}$ models along with the usage of developed computer programs (FLAC, PLAXIS) are much more developed and sophisticated than it is the case with knowing and describing geotechnical properties of the material entering a tunnel. It should not be specially emphasized that the calculation results depend extremely on a selected model and the values of relevant geotechnical parameters.

In order to secure the stability of the cavern vertical deformations from the surface will be monitored with sliding micrometer. The measurement of line deformations and soil movements along the depth with sliding micrometers is based on the measurement of relative deformations of special PVC tubes with the diameter of Ø51/63 $\mathrm{mm}$ installed into the ground. The tubes are $1 \mathrm{~m}$ long and joined with special telescopic connection joints of the profile $\varnothing 67 \mathrm{~mm}$. The joints are deformed telescopically and enable thus the measurement of relative deformations. The tubes are in- 
jected into the boreholes with the diameter of $\varnothing 100 \mathrm{~mm}$. The sliding micrometer was developed at the Swiss Federal Institute of Technology, Zürich (ETZH), and it is the product of the firm Solexperts LTD, Schwerzenbach, Switzerland. The micrometer is $1 \mathrm{~m}$ long and has the diameter of $\varnothing 47 \mathrm{~mm}$, the sensitivity of $\pm 0.001 \mathrm{~mm} / \mathrm{m}$, the precision in field conditions of $\pm 0.003 \mathrm{~mm} / \mathrm{m}$.

Such measurements combined with backward numerical analyses would enable determining the actual mechanical characteristics of the rock mass, and undertaking of measures to ensure long stability of a speleological object (Kovačević et al. 2008).

A total of 12 sliding micrometers were installed. Fig. 17 shows a plan disposition of sliding micrometers and Fig. 18 presents a characteristic cross section with marked micrometers' positions.

\section{CONCLUSION}

A speleological object of large dimensions was discovered in the "Vrata“ tunnel's right tube on the Rijeka-Zagreb highway. Speleological, geotechnical, engineering geological and hydrogeological investigation works were carried out for the purpose of preservation the speleological object (cavern). On the basis of classification results of rock masses and conducted numerical analyses the support system for the cavern's vault stabilization was selected. The support system's elements include the beamand-stringer grid constructed on the terrain's surface above the cavern, tendons and geotechnical anchors.

To ensure stability of the speleological object, and to conduct the backward numerical analyses the measurement of vertical deformations from the terrain's surface along the rock's mass by means of sliding micrometers was undertaken. Backward numerical analyses combined with geotechnical measurements enable safer and more rational approach to design and construction of underground structures. They contribute to the knowledge on rock mass performance and to determination of its physical and mechanical parameters connecting them with rock classification results. The analyses are a great help in verification or modification of elements' features of primary support system.

Tunnel and bridge in tunnel "Vrata" were opened for traffic in November 2008.

Many thanks to dr. Jo De Waele and dr. Paul Williams for initial support and suggestions in preparing this article.

\section{REFERENCES}

Garašić, M., 1981: Neotectonics in Some of the Speleological Objects in Yugoslavia. Proceedings of $8^{\text {th }} \mathrm{In}$ ternational Congress of Speleology, Bowling Green, 148-149, USA.

Garašić, M., 1989: New conception of the morphogenesis and hydrogeology of the speleological objects in karst area in Croatia (Yugoslavia). 10. International Congress of Speleology, Procceedings, vol. 1, 234-236, Budapest, Hungary.

Garašić, M., 1991: Morphological and Hydrogeological Classification of Speleological Structures (Caves and Pits) in the Croatian Karst Area. Geološki vjesnik, vol. 44, 289-300.

Garašić, M., 1993: The Karstification processes and Hydrogeological features of the Mesozoic walls in the Karst of Croatia (Europe). Proceedings of the XI International Congress of Speleology, 1-4, Beijing, China.
Garašić, M., 2007: The Longest and Deepest caves in Croatian karst. European Geosciences Union General Assembly. Vienna, Austria, $15^{\text {th }}-20^{\text {th }}$ April 2007, A-03002, GM7-1TU5P-0363, Vienna.

Garašić, M. \& Bočić, N., 2006: Deep pits and caverns in Croatia. $2^{\text {nd }}$ Middle-east speleology symposium, Proceedings, 16-25. Bejrut, MESS2 2006, Speleo-Club du Liban.

Hoek, E., Carranza-Torres, Corkum, B., 2002: HoekBrown Failure Criterion-2002 Edition. Proceedings of $5^{\text {th }}$ North American Wall Mech. Symp., Toronto, Canada, Dept. Civ. Engineering, University of Toronto, 267-273.

Kovačević, M.S., 2003: The Observational Method and the use of geotechnical measurements. XIII ${ }^{\text {th }} E C$ SMGE, Prague, $25^{\text {th }}-28^{\text {th }}$ August 2003, Prague, 575582. 
Kovačević, M.S., Jurić-Kaćunić, D., Arbanas, Ž., Petrović N., 2008: Ground Improvement by Jet Grouting Method in St. Kuzam Tunnel - Monitoring of Performance. $1^{\text {st }}$ Southern Hemisphere International Rock Mechanics Symposium SHIRMS 2008, $16^{\text {th }}-19^{\text {th }}$ September 2008, Perth, Australia, 73-84.

Kovačević, M.S., Jurić-Kaćunić, D., Ivanković, A., 2006: Interactive Geotechnical Design of Bridge Foundations. International Conference on Bridges, $21^{\text {th }}-24^{\text {th }}$ May 2006, Dubrovnik, Croatia, 275-283.
Kovačević, M.S., Skazlić, Ž., Szavits-Nossan, V., 2005: Case Histories of Very Hard Fissured Soils Stiffness Determination. Proceedings Geotechnology in Harmony with the Global Environment, XVI International Conference on Soil Mechanics and geotechnical engineering, $12^{\text {th }}-16^{\text {th }}$ September 2005, Osaka, Japan, 703-706.

Zanoškar, G. \& Garašić, M., 1992: Vrata’s sinkhole and hydrogeology of Fužine surroundings (in Croatian). Speleologica Croatica, 3, 23-26. 
